\title{
Engaging Parents in Schools and Building Parent-School Partnerships: The Role of School and Parent Organisation Leadership
}

Jenny Povey ${ }^{1}$; Alice Campbell ${ }^{1}$; Linda-Dianne Willis ${ }^{2}$; Michele Haynes ${ }^{1}$; Mark Western ${ }^{1}$; Sarah Bennett ${ }^{1}$; Emma Antrobus ${ }^{1}$; Charley Pedde ${ }^{1}$

1 Institute for Social Science Research, The University of Queensland

2 School of Education, The University of Queensland

A more recent version of this paper was published as Povey J, Campbell A, Willis L, Haynes M, Western M, Bennett S, Antrobus E and Pedde C. (2016) Engaging Parents in Schools and Building Parent-School Partnerships: The Role of School and Parent Organisation Leadership. International Journal of Educational Research, 79, 128-141 


\begin{abstract}
A growing body of research suggests that a positive school climate and Principal leadership are pivotal to building parent-school partnerships and supporting parent engagement in child learning more generally. To begin investigating these factors, surveys were distributed to Principals and Presidents of parent organisations in 1,233 Queensland State (i.e. government or public) Schools. Results indicated that although overall Principals have very positive attitudes towards parent engagement, they differ somewhat in whether or not they expect parent engagement in areas such as school governance and mandatory requirements. The most commonly perceived barriers and effective engagement strategies were identified, and differed significantly across schools according to the school's location and level of disadvantage. The implications for future research and interventions are discussed.
\end{abstract}

Keywords: parent engagement; parent involvement; school leadership; school climate; parent organisations; disadvantaged schools 


\section{Introduction}

Education is critical in today's society, with many of the conventional paths to success and financial stability dependent upon a certain level of educational attainment. Strong and consistent evidence shows that poor educational outcomes in children are associated with a range of antisocial behaviours including substance abuse, delinquent activity, long term offending behaviour, social exclusion and isolation, teenage pregnancy, unemployment and future dependency on social services (Henry \& Huizinga, 2007a, 2007b; Stranger, 2002). In an increasingly globalised and technological world, job market success in developed countries such as Australia depends on the attainment of post-secondary qualifications (Ministerial Council for Education, Employment, Training and Youth Affairs [MCEETYA], 2008). Australian Commonwealth, State and Territory Education Ministers have declared that improving the educational outcomes of young Australians is central to the future well-being and prosperity of Australia, and to ensuring that all young Australians have an equal opportunity to live productive and fulfilling lives (MCEETYA, 2008).

The quality of educational outcomes of Australian children has been a matter of some concern for recent Australian governments, educational researchers and the general public (Department of Education and Training [Australian Government], 2015a; Thomson, 2013; Wilson, Dalton, \& Baumann, 2015). Australian students have performed below the average on a number of recent international achievement measures (Thomson, De Bortoli, \& Buckley, 2012), and their results in the Organisation for Economic Co-operation and Development (OECD) Programme for International Student Assessment (PISA) have shown a steady decline since the tests were first implemented in 2000 (Thomson, 2013). Of further concern, approximately two-and-a-half years of schooling separates the achievement scores of students in the highest and lowest socioeconomic quartiles, and student achievement differs significantly according to location (e.g. rural or metropolitan) and cultural background (Thomson, 2013). All Australian governments have recognised the need to increase quality and equity in Australian schooling (Council of Australian Governments [COAG], 2013), and one of the key ways in which they are seeking to achieve this is through improving parent-school partnerships and parent engagement in child learning (Department of Education and Training [Australian Government], 2015b; MCEETYA, 2008).

The critical importance of engaging parents in their child's learning and building parent-school partnerships has been established in the international literature but research in the Australian 
context is limited. The research presented here is part of a larger project focused on increasing levels of parent engagement and improving parent-school partnerships. Before this lofty goal can be realised, the current study provides the necessary foundation by investigating aspects of school climate, Principal leadership and the role of parent organisations as they relate to parent engagement in Australian schools. To contextualise the research, the following section provides a review of the literature on parent engagement in child learning, parent-school partnerships, school climate, Principal leadership and parent organisations.

\section{Literature review}

\subsection{Parent engagement in child learning}

Parent engagement is broadly defined as the behaviours, values, attitudes and activities of parents that promote their child's academic development, ability to learn and educational outcomes (Department of Education and Training [Australian Government], 2015c). More specifically, improved learning outcomes have been found when parents engage with their child's learning at home by reading and playing mathematics games together, communicating high educational expectations, and talking with their child about their school activities and interests (Castro et al., 2015; Fox \& Olsen, 2014; Harris \& Goodall, 2007; Perkins \& Knight, 2014; Van Voorhis, Maier, Epstein, \& Lloyd, 2013). Such forms of parent engagement have also been shown to benefit children's social and emotional development (Chazan-Cohen et al., 2009; Fantuzzo, McWayne, Perry, \& Childs, 2004; Mistry, Benner, Biesanz, \& Clark, 2010; Powell, Son, File, \& San Juan, 2010), and improve student attendance and school retention (McNeal, 2001). This vast body of literature clearly demonstrates the many benefits that arise when parents engage with their child's learning at home. Yet another important aspect of parents' engagement with their child's learning is involvement and collaboration with their child's school.

\subsection{Parent-school partnerships}

It has been widely argued that optimal child learning outcomes occur when the key educators in a child's life, that is parents and schools, form respectful and collaborative partnerships with one another and work towards common goals (Emerson, Fear, Fox, \& Sanders, 2012; Epstein, 2011; Fox \& Olsen, 2014; Goodall \& Montgomery, 2014). For example, Goodall and Montgomery's (2014) model of parent engagement conceptualises agency for child learning as belonging to parents, supported by schools. Emerson et al. (2012) state that parent involvement 
within schools can act as a precursor to effective practices at home. There is also evidence to suggest that parents are more likely to be engaged in their child's learning at home when schools have high expectations for them to do so and provide commensurate practical support (Dauber \& Epstein, 1989; Eccles \& Harold, 1996; Parental Engagement Project Taskforce, 2011; Toldson \& Lemmons, 2013; Whitaker \& Hoover-Dempsey, 2013). Schools may be wellplaced to help build the capacity of parents by training them in aspects of the curriculum (Emerson et al., 2012, Fox \& Olsen, 2014; Parental Engagement Project Taskforce, 2011). For example, Senechal and Young (2008) found that training parents to tutor their child in specific literacy skills significantly benefited the child's reading ability. Schools can also promote the benefits of parent engagement and facilitate the mutual sharing of information about the child's wellbeing and progress (Emerson et al., 2012; Fox \& Olsen, 2014; Parental Engagement Project Taskforce, 2011).

Although previous reviews of the relevant research concluded that the direct relationship between parent involvement in schools (e.g. in the forms of volunteering and attending social events) and children's learning outcomes is small (Jeynes, 2005; Van Voorhis et al., 2013), such involvement can help parents to build supportive social networks, develop positive relationships with school staff, and understand school norms (Fox \& Olsen, 2014). This may be particularly important for parents from disadvantaged backgrounds, who are at greater risk of experiencing barriers to both forming partnerships with schools and engaging in their child's learning more generally (Fox \& Olsen, 2014; Kim, 2009; Turney \& Kao, 2009).

Levels of parent involvement in schools have been shown to decrease markedly as children enter adolescence and transition to secondary school (Epstein, 1990; Wang and Sheikh-Khalil, 2014; Zill \& Nord, 1994). It has been proposed that more appropriate forms of parent engagement at this stage of a child's life involve scaffolding a child's decision-making and future planning capabilities and socialising them around the goals and benefits of education: a type of engagement referred to as academic socialisation (Hill \& Tyson, 2009). Certainly, Hill and Tyson's (2009) meta-analysis found that academic socialisation has a stronger relationship with adolescents' academic achievement than parent involvement in schools. However, parent involvement in forms such as volunteering and attending school events was still found to have a moderate, positive association with adolescent learning outcomes. Wang and Sheikh-Khalil (2014) found that parents' school involvement had a significant, indirect association with adolescents' academic and mental health outcomes, mediated by the child's emotional engagement with their schooling (i.e. how much they enjoy and value their schooling). 
Therefore, supporting parents' continued involvement in their child's school as they transition from primary to secondary schooling is likely to benefit child learning outcomes.

Given the crucial role that schools can play in supporting parents' engagement with their child's learning and the mutual benefits that flow from parent-school partnerships, it is essential to identify which aspects of a school may enable such successful collaboration. A review of the current literature suggests that school climate and leadership may play key roles.

\subsection{School climate}

A growing body of research suggests that for schools to successfully form partnerships with parents, a positive school climate is required (Gavidia-Payne, Denny, Davis, Francis, \& Jackson, 2015; Goldkind \& Farmer, 2013; Kaplan Toren \& Seginer, 2015; Wallace 2013; Whitaker \& Hoover-Dempsey, 2013). School climate is defined as the subjective experience of the quality and character of school life, as reflected in the norms, goals, values, relationships, organizational structure and methods of teaching and learning within the school (National School Climate Council, 2007). Certain aspects of school climate appear to be particularly important for building parent-school partnerships and engaging parents in their child's learning. For example, levels of parent engagement appear to be higher when teachers: have a positive relationship with the child, care about the child's academic development, and are perceived by parents as approachable and communicating frequently (Eccles \& Harold, 1996; Gavidia-Payne et al., 2015; Hayes, 2011; Kaplan Toren \& Seginer, 2015; Watkins, 1997). Furthermore, higher levels of parent engagement have been associated with an overall school climate perceived by parents as safe, trustworthy, respectful, friendly, inclusive and collaborative (Day, 2013; Goldkind \& Farmer, 2013; Griffith, 1998; Whitaker \& HooverDempsey, 2013). Conversely, disengaged parents have cited a negative school climate as a barrier to their becoming more involved with the school and engaged in their child's learning (Barr \& Saltmarsh, 2014; Day, 2013; Hanafin \& Lynch, 2002).

A school's climate is created partly through relationships and interactions among all members of a school community (National School Climate Council, 2016), including students, teachers, parents and guidance officers. However, those in leadership positions within the school, most notably the school Principal and President of the school's parent organisation, may be particularly influential in shaping the school's climate when it comes to parent engagement. 


\subsection{Principal leadership}

School Principals appear to play a central role in shaping school climate and facilitating parent engagement in child learning through their leadership style, communication, attitudes and expectations (Barr \& Saltmarsh, 2014; Drysdale, Goode, \& Gurr, 2009; Giles, 2006; Gordon \& Louis, 2009; Mleczko \& Kington, 2013). When it comes to identifying the precise mechanisms through which this occurs however, the current literature is far from conclusive. In one study, parents reported their perception that the Principal had a direct influence on school climate through their own personal vision that then filtered down to other staff in a top-down manner (Barr \& Saltmarsh, 2014). Mleckzo and Kington (2013) similarly argue that levels of parent involvement in schools increase when Principals actively embed a whole school vision that values the role of parents in their child's learning. These researchers further argue that Principals who distribute school leadership among parents and teachers will be more successful in accomplishing this goal.

In Mleckzo and Kington's (2013) investigation of two United Kingdom schools - each with relatively high proportions of disadvantaged students and learning outcomes above those of comparable schools - the successful Principals used two-way communication and incorporated the ideas of parents and staff to involve and help them feel included. Another way that Principals influence the school climate, as it relates to parent engagement, is through facilitating or restricting parents' access to teachers (Barr \& Saltmarsh, 2014; Mleczko \& Kington, 2013). It is also possible that Principals who value parent engagement may be more likely to provide training opportnities for teaching staff to build their skills in working with parents - something that $82 \%$ of Australian teachers identified as their greatest professional development need (Doecke et al., 2008). Clearly there is still much to be learned about how Principals foster parent-school partnerships, and what makes some Principals more successful at this than others. Another potentially influential yet under-researched figure in the school, someone who is in a position to form collaborative partnerships with both parents and Principals, is the President of the school's parent organisation.

\subsection{The role of parent organisations}

Internationally, parent organisations provide a well-recognised and structured way for parents to engage with their child's school (Pakseresht \& Ahari, 2014), and involvement in parent organisations has been used as a proxy measure of parent engagement in some studies (Garcia, 2004; Hill \& Taylor, 2004). Parent organisations create potential channels for Principals and 
teachers to consult with the parents and community about school matters (Ekundayo \& Alonge, 2012; Gianzero, 1999; I-wah, 1997; Khong \& Ng, 2005; Ozmen \& Canpolat, 2010; Shakur, 2012). They can have an important influence on the school climate and the extent to which all parents feel comfortable at the school (Gianzero, 1999), although in some instances they can foster division and exclusivity (Cheung, Lam, \& Ngai, 2008). Most international research investigating parent attitudes towards parent organisations has found that parents rate the organisations positively (I-wah, 1997; Pakseresht \& Ahari, 2014; Payne, Hinds, \& Gay, 1986).

Research in the Australian context has been sparse, and focused mainly on documenting the role of parent organisations using qualitative methods (e.g. Gow, 2008). Gow's (2008) analysis of parent organisations from 1921 to 1991 in the Riverina area, New South Wales, showed that they made a vital contribution to schools by establishing firm links with the community. These links then allowed the community to support the schools and vice-versa. Hence, it is likely that parent organisations play a central role in building parent-school partnerships in some schools, however, further research is needed to establish the conditions under which this takes place.

In Queensland, parent organisations in State Schools are called Parents and Citizens (P\&C) Associations. They are established under the Education (General Provisions) Act 2006 (Q1d). $\mathrm{P} \& \mathrm{C}$ Associations are represented by the overarching peak body P\&Cs Qld, whose aims and objectives include promoting closer cooperation between principals, teachers, students and parents and involvement in all areas of education affecting the parent, school and community (P\&Cs Qld, 2016). Membership of P\&C Associations is open to interested persons over the age of 18, including parents of current students, members of the community (citizens), students over the age of 18 and staff members of the school (Kelso, 2013). The executive of a P\&C Association is comprised of the President (hereafter referred to as the P\&C President), VicePresident, Secretary and Treasurer. The P\&C President's role includes providing leadership, fostering good communication between the Association, school and community, and encouraging participation (Kelso, 2013).

The aim of the research presented here was to gather baseline school level data, in the Australian context, on the leadership role school Principals and Parent Organisation play in shaping school climate and facilitating parent engagement in child learning. This research will add to the existing body of literature by: exploring in greater depth than previously seen, the role and perspectives of the President of the school parent organisation with regards to parent engagement; adding to a growing body of knowledge about the role of school Principals and 
school climate; and identifying how the uptake of engagement strategies differs across Australian schools according to location, type and level of advantage. The findings from this research will provide a solid foundation for the future development and implementation of interventions in schools aimed at increasing levels of parent engagement and improving parentschool partnerships.

\section{Method}

The data used for this paper were obtained from the Parent Engagement in Schools (PES) project, which collected data from State Schools in Queensland, Australia. The State of Queensland has a population of approximately 4.8 million people (Australian Bureau of Statistics, 2015), making it the third most populous of Australia's six States and two Territories. Demographically, the Queensland population is broadly representative of the other Australian states (Queensland Government, 2012). It is also representative educationally based on the latest nation-wide assessment of Australian students on literacy and numeracy achievement such that the average performance of Queensland students did not differ significantly from the national mean (Australian Curriculum Assessment and Reporting Authority [ACARA], 2015).

\subsection{Participants}

The sampling frame used for this study was all 1,233 State schools in Queensland in $2014^{1}$. A total of 729 Queensland State Schools participated in the study (457 Principals and 492 P\&C Presidents). Of these, completed surveys were received from 618 schools (385 from Principals and 402 from P\&C Presidents). Data were collected from both the Principal and P\&C President for 169 schools. The sample of 618 schools comprised 427 primary schools, 26 special schools, 122 secondary schools and 43 combined (primary/secondary) schools. Schools varied in their location, with 67 situated in a remote zone, 212 in a rural zone, 59 in a provincial city zone and 280 in a metropolitan zone. The schools also varied in their Index of Community SocioEducational Advantage (ICSEA) score. School ICSEA values are a composite of student socioeducational status (parent occupation and education), school remoteness, and percentage of Indigenous students and those from a Language Background Other than English (LBOTE) (Barnes, 2010). A total of 55 schools had an ICSEA value more than one standard deviation below the national median $(<900), 341$ schools had an ICSEA value up to one standard

\footnotetext{
${ }^{1}$ One school requested to take part in the study at a campus rather than whole-school level, as it comprises 17 campuses across the Torres Strait that can be up to 80 kilometres apart. It was decided that this school would be represented at the disaggregate level, and adjusting for this brought the total sampling frame to 1,249.
} 
deviation below the national median (900-999) and 222 schools had an ICSEA value at or above the national median $(1,000+)$.

Descriptive analyses, including chi-square goodness of fit tests and one sample t-tests, were conducted to compare the characteristics of participating schools (e.g. those with completed surveys by Principals and/or P\&C Presidents) with the overall population of Queensland State Schools (Table 1). As Table 1 shows, participating Principals were associated with schools that were broadly representative of all Queensland State Schools with regards to location, ICSEA score, school size, and proportion of Indigenous and LBOTE students. However, Principals from secondary schools were over-represented in the sample and those from Primary schools under-represented. Participating P\&C Presidents were disproportionately from secondary schools, schools with a high ICSEA value, and those located in a metropolitan zone. Their schools had significantly higher enrolments than the Queensland State School mean, and significantly lower proportions of Indigenous students. 
Table 1. Characteristics of participating schools compared to the population of Queensland State Schools

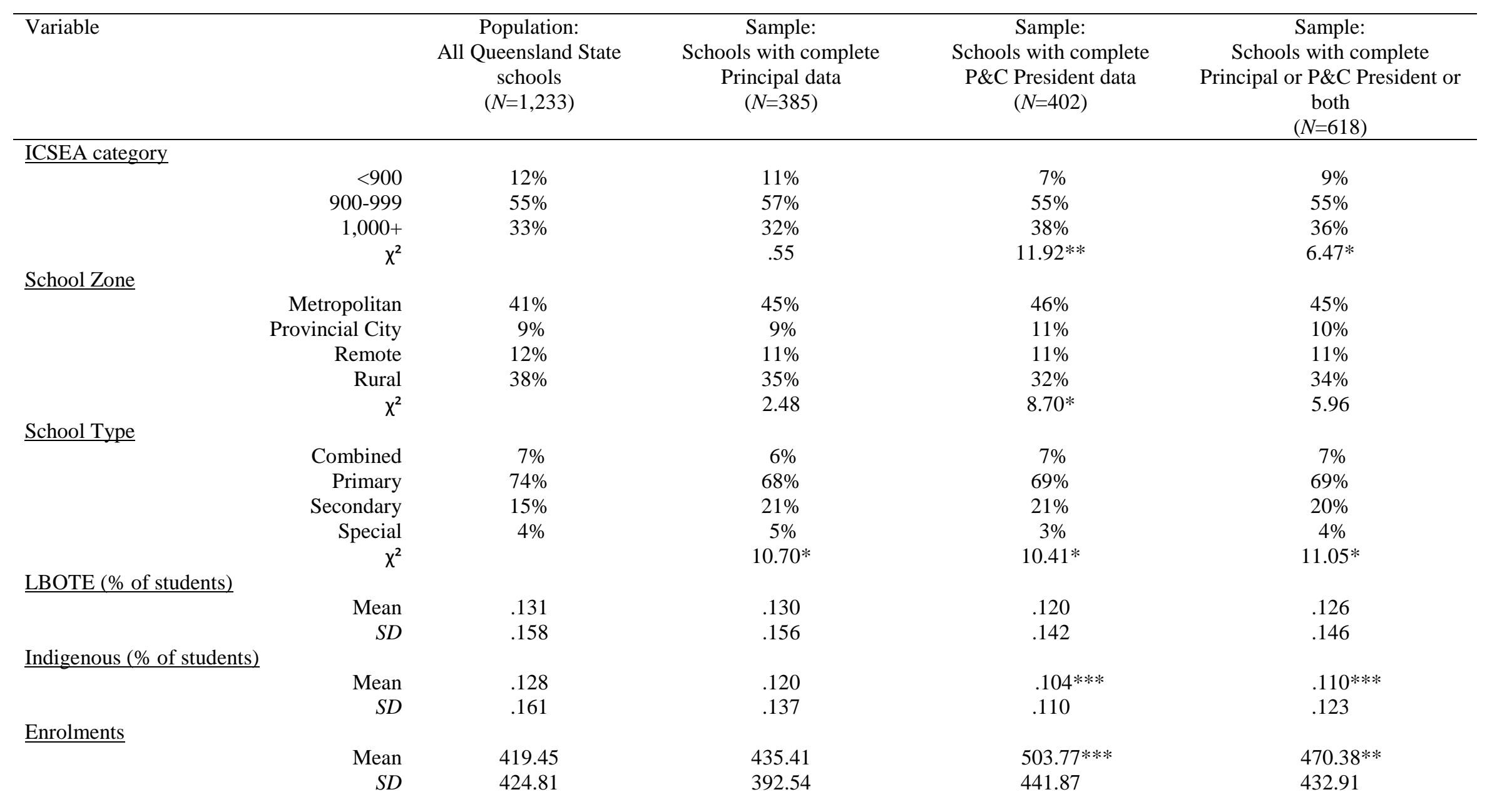

Note. Differences in frequencies for categorical variables between population and samples were assessed using chi-square goodness of fit tests; differences between means for continuous variables were assessed using one sample t-tests.

$* p<.05$. *** $p<.01$. **** $p<.001$. 


\subsection{Instrumentation}

The separate Principal and P\&C President surveys were designed by the Parent Engagement in Schools (PES) project team at The University of Queensland, with measures created following an extensive literature review and refined by input from an expert panel (including representatives from the Queensland Department of Education and Training and the peak parent organisation body, P\&Cs Queensland). Some of the survey items were inspired and adapted from the Belfast Education and Library Board (BELB) Survey 2007-2008 and OECD Teaching and Learning International Survey (TALIS) Principal Questionnaire. A Principal parent engagement leadership scale was developed for the purpose of this study, and future publications will validate this measure.

Principals and P\&C Presidents were asked about their perceptions of the benefits and barriers to parent engagement in the life of the school, the Principal's leadership style and the Principal's relationship with parents, frequency and methods of communication with parents, and the use and effectiveness of different methods to engage parents in their school. Additionally, Principals were asked about their expectations surrounding parent involvement in school life and student learning, and P\&C Presidents were asked about parent volunteering in the school. Table 2 shows the final composition of the Principal and P\&C President Survey questionnaires. The final versions of the survey took approximately 20 minutes to complete and were offered in an online mode or, where requested, hard copy. Each survey included a unique code, which enabled the administrative school data provided by the Queensland Department of Education and Training to be linked to the survey data.

\subsection{Procedure}

The PES team sent personal invitations in August 2014 to every State School Principal and P\&C President in Queensland whose contact details were available via the relevant supervising body. For the remainder of the schools, a generic administrative email address was used. Twenty school Principals and three P\&C Presidents refused to take part in the study. Only one school indicated that they did not have a P\&C Association.

P\&Cs Qld advertised the survey in their newsletter and via twitter. Principal Associations were contacted and informed of the survey. Principals were asked to check that the P\&C President received the invitation to participate and vice versa. Participation in the survey was voluntary. Six reminder emails were sent between August 2014 and November 2014 when data collection closed. Four weeks into the data collection, preliminary results from the study were presented at a $\mathrm{P} \& \mathrm{C}$ annual State conference and schools that had not yet participated and were present at the conference, were provided the opportunity to collect a hardcopy survey. 
Table 2. Composition of Principal and P\&C President Survey questionnaires

\begin{tabular}{|c|c|c|c|c|}
\hline Constructs & Number of items & Example items & Response Scale & Survey \\
\hline Principal Leadership Style & 10 & $\begin{array}{l}\text { I play an integral role in promoting parental engagement in } \\
\text { our school } \\
\text { I think that parental engagement is an unnecessary } \\
\text { interference in school affairs }\end{array}$ & $\begin{array}{l}1 \text { (Strongly Disagree) - } \\
5 \text { (Strongly Agree) }\end{array}$ & $\begin{array}{l}\text { Principal and } \\
\text { P\&C President }\end{array}$ \\
\hline Principal's Relationship with Parents & 9 & $\begin{array}{l}\text { I treat parents in the school with respect } \\
\text { Parents in the school don't trust me }\end{array}$ & $\begin{array}{l}1 \text { (Strongly Disagree) - } \\
5 \text { (Strongly Agree) }\end{array}$ & $\begin{array}{l}\text { Principal and } \\
\text { P\&C President }\end{array}$ \\
\hline Principal's Attitude Towards P\&C & 6 & $\begin{array}{l}\text { The current } P \& C \text { is ineffective } \\
\text { The } P \& C \text { takes up too much of my time }\end{array}$ & $\begin{array}{l}1 \text { (Strongly Disagree) - } \\
5 \text { (Strongly Agree) }\end{array}$ & Principal only \\
\hline Benefits of Parent Engagement & 7 & $\begin{array}{l}\text { Student learning outcomes } \\
\text { Social capital in the school community }\end{array}$ & $\begin{array}{l}1 \text { (Strongly Disagree) - } \\
5 \text { (Strongly Agree) }\end{array}$ & $\begin{array}{l}\text { Principal and } \\
\text { P\&C President }\end{array}$ \\
\hline Barriers to Parent Engagement & 17 & $\begin{array}{l}\text { Work commitments } \\
\text { Parents lack confidence }\end{array}$ & $\begin{array}{l}1(\text { Not at all })- \\
5 \text { (To a great extent }) \\
\quad \text { or 'N/A' }\end{array}$ & $\begin{array}{l}\text { Principal and } \\
\text { P\&C President }\end{array}$ \\
\hline Effective Methods for Engaging Parents & 25 & $\begin{array}{l}\text { Communicating using a variety of methods } \\
\text { Making yourself available and visible }\end{array}$ & $\begin{array}{l}1 \text { (Ineffective) }- \\
5 \text { (Very Effective) } \\
\text { or "Not Used" }\end{array}$ & $\begin{array}{l}\text { Principal and } \\
\text { P\&C President }\end{array}$ \\
\hline Expectations for Parent Involvement & 26 & $\begin{array}{l}\text { Supporting their child's learning at home } \\
\text { Attending parent information evenings }\end{array}$ & $\begin{array}{l}1(\text { Not at all })- \\
\text { (To a Great Extent }) \\
\quad \text { or 'N/A' }\end{array}$ & Principal only \\
\hline Communication & 11 & $\begin{array}{l}\text { How often does your school use the following means of } \\
\text { communication to share student related information with } \\
\text { individual parents - phone calls }\end{array}$ & $\begin{array}{l}\text { Daily/Weekly/Fortnightly/ } \\
\text { Monthly/A few times a year/ } \\
\text { Never }\end{array}$ & Principal only \\
\hline Parent Volunteering & 8 & $\begin{array}{l}\text { We have lists of parents who are always willing to help } \\
\text { We have had to cancel events due to a lack of volunteers }\end{array}$ & Tick all that apply & P\&C President only \\
\hline
\end{tabular}




\subsection{Data analysis}

Data from the surveys were analysed using Stata Statistical Software: Release 14 (StataCorp, 2015). Descriptive and inferential statistical analyses included frequencies, cross-tabulations and chi-square tests of significance. Due to very small cell sizes in some response categories, items assessing perceived benefits and barriers, Principal's relationship with parents, Principal's attitudes towards the $\mathrm{P} \& \mathrm{C}$ and effective engagement methods were converted into binary variables, such that values of four and five were collapsed into one category (conceptualised as representing agree/to a great extent/effective) and the values one, two, and three were collapsed into another category (conceptualised as representing do not agree/not a great extent/not effective).

\section{Results}

The results of the Principal and $\mathrm{P} \& \mathrm{C}$ President surveys are presented together in the following order: perceived benefits of parent engagement, perceived barriers to parent engagement, effective engagement methods, parent volunteerism, Principal's expectations, Principal leadership, parent-school relationships and communication. Within each of these eight categories, frequencies are presented and the least and/or most common responses identified. Any significant differences according to school ICSEA, type and location are also described.

\subsection{Benefits of parent engagement}

Principals and P\&C Presidents held positive attitudes towards parent engagement overall, with the vast majority endorsing all of the proposed benefits of parent engagement, including: enhanced student learning outcomes (97\% Principals; 93\% P\&C Presidents), student attendance $(99 \% ; 93 \%)$, positive student behaviour (99\%; 95\%), school retention of students $(96 \% ; 89 \%)$, school culture (94\%; 96\%), self-development among parents $(85 \% ; 84 \%)$, and social capital $(93 \% ; 90 \%)$. Principals from secondary schools were significantly less likely to endorse 'personal development of parents' as a benefit of parent engagement compared with their primary school counterparts $\left(\chi^{2}(1, N=385)=8.147, p<.01\right)$. P\&C Presidents from secondary schools were also significantly less likely to endorse this benefit of parent engagement compared with their primary counterparts $\left(\chi^{2}(1, N=402)=6.833, p<.01\right)$. No other differences were observed in Principals' and P\&C Presidents' endorsement of benefits across school zones (i.e., rural, remote, provincial, or metropolitan) or ICSEA categories. 


\subsection{Barriers to parent engagement}

Time pressures appear to be a significant factor inhibiting parent involvement in schools, with the barriers most frequently identified by Principals and P\&C Presidents including: work commitments (89\% of Principals; $85 \%$ of P\&C Presidents), family commitments (75\%; 59\%), caring responsibilities (57\%; 47\%) and timing of events $(57 \% ; 36 \%)$. A lack of parent interest was also identified as a barrier by $56 \%$ of Principals and $63 \%$ of $\mathrm{P} \& \mathrm{C}$ Presidents.

Parents in disadvantaged schools appeared to experience different barriers to becoming involved compared with parents in more advantaged schools. As shown in table 3, Principals from lower ICSEA schools were significantly more likely to identify a number of barriers as reducing parent involvement, including transportation problems, a lack of parent interest, lack of trust in the responsiveness of the school to parent concerns, the parents not feeling capable, and the parents lacking confidence. Time pressures appear to be less of a barrier in these schools, with P\&C Presidents from lower ICSEA schools being less likely to identify work commitments, family commitments and caring responsibilities as barriers. This is important information that may help guide future interventions aimed at increasing levels of engagement in disadvantaged schools.

Secondary school P\&C Presidents were significantly more likely than their primary counterparts to identify a lack of parent confidence and an unwelcoming school environment as barriers to parents becoming involved, information that again may be useful for guiding interventions in these schools.

\subsection{Effective methods for engaging parents}

There was general agreement between Principals and P\&C Presidents surrounding the most effective ways to engage parents in their school, with both groups most likely to nominate the following methods as effective: creating a respectful and welcoming environment $(93 \%$ of Principals; $67 \%$ of P\&C Presidents), being flexible in accommodating the needs of parents and families $(88 \% ; 61 \%)$, and recognising volunteers $(88 \% ; 62 \%)$.

As Table 4 shows, a number of methods were less likely to be rated by Principals as effective as the ICSEA value of the school decreased. This included, but was not limited to: offering workshops/programs to support parent learning, supporting parents to help their children's' learning at home, providing a variety of volunteer opportunities, communicating high expectations about school involvement, and encouraging parents to be part of decision making. 
Similarly, P\&C Presidents were less likely to rate the following methods as effective as the ICSEA value of the school decreased: creating a respectful and welcoming environment $\left(\chi^{2}(2\right.$, $N=398)=15.80, p<.001)$, communicating the benefits of parent engagement to their child $\left(\chi^{2}\right.$ $(2, N=374)=10.66, p<.01)$, and communicating high expectations about school involvement $\left(\chi^{2}(2, N=347)=11.24, p<.01\right)$. No method was more likely to be rated as effective in lower ICSEA schools, which suggests overall that disadvantaged schools are less successful than their more advantaged counterparts in their attempts to engage parents.

A number of methods were less likely to be rated effective by secondary school Principals, such as providing a variety of volunteer opportunities, and offering workshops and programs to support parents' learning (see Table 4). It is possible that secondary schools find their attempts to engage parents less effective at least in part as a result of those barriers previously identified as being more common in secondary schools, including an unwelcoming school environment and a lack of parent confidence.

Most methods used to engage parents were found to be equally effective across zones. However, Principals in remote areas were more likely to classify collaborating with the community as an effective method $\left(\chi^{2}(3, N=382)=10.76, p<.05\right)$. 
Table 3. Percentage of Principals and P\&C Presidents identifying barriers to parent engagement by ICSEA, school type and zone

\begin{tabular}{|c|c|c|c|c|c|c|c|c|c|c|c|c|}
\hline & \multicolumn{3}{|c|}{ School ICSEA } & \multirow[b]{3}{*}{$\chi^{2}$} & \multicolumn{3}{|c|}{$\underline{\text { School Type }}$} & \multicolumn{4}{|c|}{ School Zone } & \multirow[b]{3}{*}{$\chi^{2}$} \\
\hline & $<900$ & $\begin{array}{l}900- \\
999\end{array}$ & $\begin{array}{c}1000 \\
+\end{array}$ & & Primary & Secondary & & Remote & Rural & $\begin{array}{l}\text { Provincial } \\
\text { City }\end{array}$ & Metropolitan & \\
\hline & $\%$ & $\%$ & $\%$ & & $\%$ & $\%$ & $\chi^{2}$ & $\%$ & $\%$ & $\%$ & $\%$ & \\
\hline \multicolumn{13}{|l|}{ Principals } \\
\hline Work Commitments & 74 & 89 & 94 & $14.01 * * *$ & 88 & 95 & 3.26 & 84 & 93 & 100 & 86 & $10.36^{*}$ \\
\hline Family Commitments & 64 & 75 & 77 & 2.72 & 71 & 85 & $5.97 *$ & 63 & 79 & 79 & 73 & 4.80 \\
\hline Timing of Events & 48 & 56 & 63 & 3.55 & 57 & 57 & .00 & 51 & 64 & 53 & 54 & 4.36 \\
\hline Caring Responsibilities & 60 & 55 & 59 & .58 & 53 & 60 & 1.13 & 44 & 59 & 62 & 58 & 3.37 \\
\hline Lack of Parent Interest & 61 & 62 & 43 & $12.33 * *$ & 56 & 54 & .08 & 56 & 63 & 62 & 49 & 6.14 \\
\hline Lack of Confidence & 67 & 60 & 42 & $12.20 * *$ & 54 & 52 & .15 & 42 & 61 & 65 & 51 & 7.77 \\
\hline Transportation Problems & 68 & 49 & 45 & $6.77 *$ & 49 & 48 & .01 & 56 & 55 & 47 & 44 & 4.31 \\
\hline Parents Don't Feel Capable & 64 & 51 & 34 & $15.39 * * *$ & 47 & 46 & .06 & 30 & 53 & 59 & 44 & $9.11^{*}$ \\
\hline $\begin{array}{l}\text { Lack of Trust in the Responsiveness of the } \\
\text { School to Parent Concerns }\end{array}$ & 22 & 24 & 13 & $6.68^{*}$ & 21 & 20 & .02 & 19 & 22 & 24 & 19 & .87 \\
\hline \multicolumn{13}{|l|}{$\underline{\mathrm{P} \& \mathrm{C} \text { Presidents }}$} \\
\hline Work Commitments & 65 & 85 & 89 & $9.59 * *$ & 85 & 86 & .03 & 69 & 83 & 84 & 90 & $13.22 * *$ \\
\hline Family Commitments & 46 & 54 & 68 & $9.95 * *$ & 56 & 67 & 3.55 & 24 & 60 & 68 & 64 & $25.99 * * *$ \\
\hline Timing of Events & 27 & 34 & 40 & 2.61 & 37 & 35 & .07 & 25 & 39 & 39 & 36 & 2.81 \\
\hline Caring Responsibilities & 35 & 43 & 55 & $6.82 *$ & 45 & 50 & .54 & 27 & 45 & 52 & 51 & $9.00^{*}$ \\
\hline Lack of Parent Interest & 88 & 66 & 55 & $12.33^{* *}$ & 63 & 65 & .10 & 56 & 65 & 75 & 61 & 4.27 \\
\hline Lack of Confidence & 48 & 35 & 32 & 2.52 & 31 & 47 & $7.53 * *$ & 16 & 38 & 57 & 32 & $17.42 * * *$ \\
\hline Parents Don't Feel Capable & 32 & 27 & 26 & .42 & 24 & 34 & 3.05 & 7 & 28 & 38 & 28 & $11.56^{* *}$ \\
\hline The School Environment is not Welcoming & 4 & 9 & 3 & $6.59^{*}$ & 4 & 13 & $8.52 * *$ & 7 & 7 & 2 & 7 & 1.33 \\
\hline Other Parents are not Welcoming & 23 & 9 & 8 & $6.31^{*}$ & 11 & 6 & 1.54 & 7 & 10 & 7 & 10 & .96 \\
\hline $\begin{array}{l}\text { Lack of Communication between } \\
\text { teachers/parents/children }\end{array}$ & 23 & 23 & 28 & 1.20 & 25 & 25 & .00 & 13 & 22 & 16 & 32 & $10.33^{*}$ \\
\hline
\end{tabular}


Table 4. Percentage of Principals rating methods of engagement as effective by school type and ICSEA

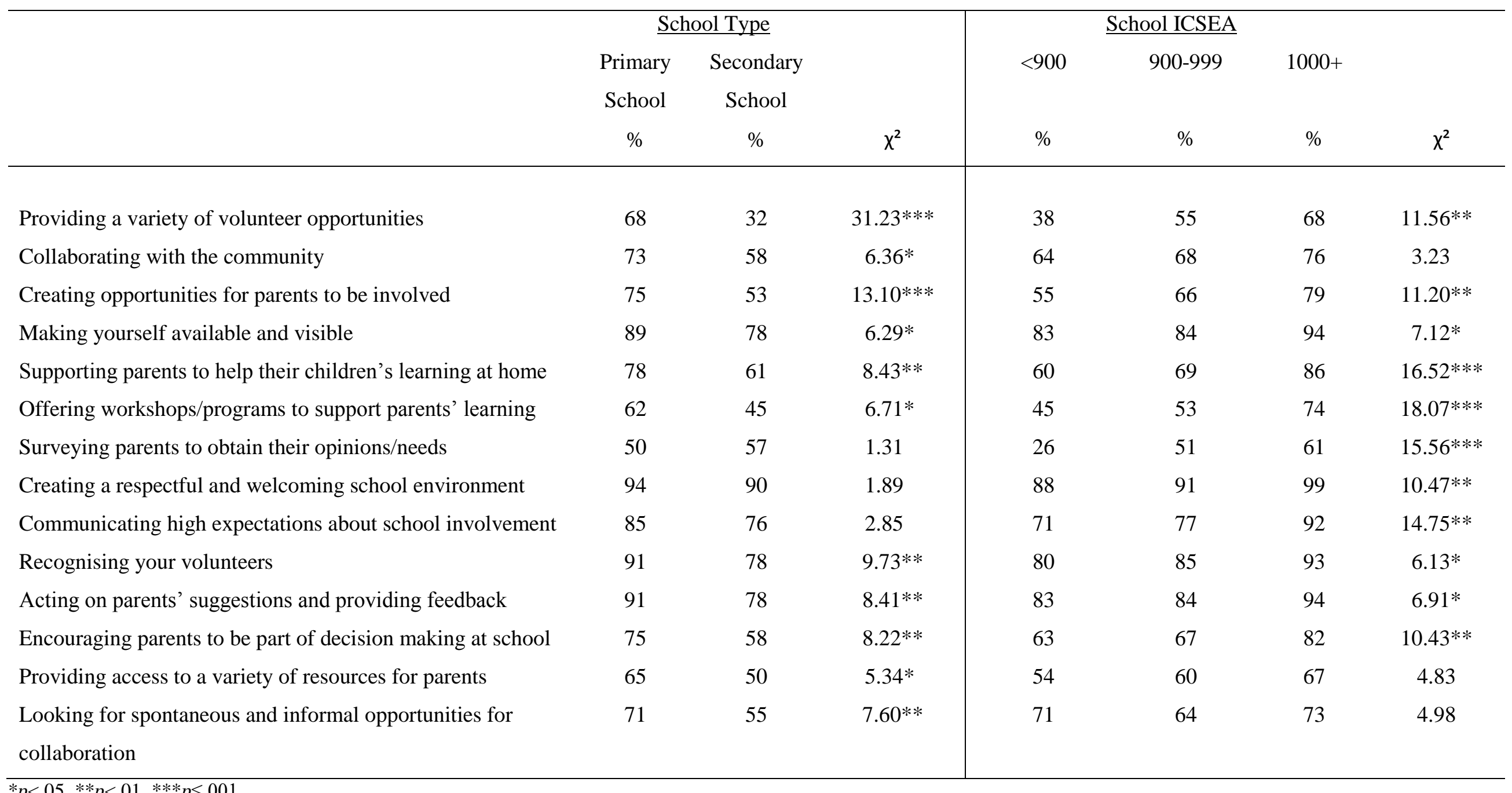




\subsection{Parent volunteerism}

Almost half (48\%) of P\&C Presidents indicated that they have a list of parents always willing to help, and 35\% indicated that they use small groups that network with parents and obtain help that way. However, $49 \%$ of P\&C Presidents endorsed the statement that, although they have lists and use networks, they still struggle to get enough volunteers. Just over $10 \%$ of P\&C Presidents indicated that they had cancelled events due to a lack of volunteers.

Volunteer recruitment and uptake differed across school type and ICSEA, with disadvantaged schools and secondary schools reporting a less positive culture of parent volunteerism. This is unsurprising given that a number of engagement strategies, as noted earlier, were less likely to be perceived as effective in these schools. P\&C Presidents from schools with an ICSEA below 900 were significantly more likely than P\&C Presidents from schools with an ICSEA of 1,000 or more to report struggling to enlist volunteers and having to 'beg and plead' (52\% versus $\left.28 \%, \chi^{2}(2, N=402)=6.31, p<.05\right)$ and not organising events due to parents not volunteering $\left(22 \%\right.$ versus $\left.5 \%, \chi^{2}(2, N=402)=9.79, p<.01\right)$. Secondary school P\&C Presidents were significantly less likely than their primary counterparts to have a list of parents always willing to help $\left(35 \%\right.$ versus $\left.53 \%, \chi^{2}(1, N=402)=8.70, p<.01\right)$, and significantly more likely to not organise events due to parents not volunteering $\left(23 \%\right.$ versus $5 \%, \chi^{2}(1, N=402)=25.50, p$ $<.001)$.

Volunteer recruitment and uptake also differed across school location, with P\&C Presidents from remote schools the most likely to have lists of parents always willing to help (59\%), while parents from provincial city schools were the least likely to have such lists $(32 \%), \chi^{2}(3, N=$ $402)=11.96, p<.01$. However, $\mathrm{P} \& \mathrm{C}$ Presidents from remote schools were the least likely to use small groups that network with parents and obtain help that way (26\%), while parents from metropolitan schools were the most likely to recruit volunteers this way $\left(42 \%, \chi^{2}(3, N=402)\right.$ $=8.29, p<.05)$.

\subsection{Principals' expectations for parent engagement}

The aspects of school life that Principals most frequently expected parents to be involved in were: parent-teacher interviews (98\%), supporting children's learning at home (97\%), the P\&C Association (95\%), uniform policy (91\%), and volunteering (91\%). Only a minority of Principals expect parent involvement in aspects of school operations including: school governance $(35 \%)$, evaluating the Principal's performance $(35 \%)$, risk management policy 
(33\%), school building maintenance (29\%), business operations (14\%), and curriculum design (9\%). Principals' expectations did not differ significantly across school ICSEA or location; however, they did differ between primary and secondary schools. Table 5 below shows the areas of school life that Principals from secondary schools are significantly less likely to expect parents to be involved in compared with their primary counterparts.

Table 5. Principals' expectations for parent involvement by school type

\begin{tabular}{lccc}
\hline & Primary & Secondary & \\
& $\%$ & $\%$ & $\chi^{2}$ \\
\hline Helping in the classroom & $83 \%$ & $27 \%$ & $88.55^{* * *}$ \\
Grant writing & $62 \%$ & $36 \%$ & $16.26^{* * *}$ \\
Fundraising & $94 \%$ & $66 \%$ & $40.19^{* * *}$ \\
Volunteering (e.g. school fetes) & $94 \%$ & $83 \%$ & $7.97 * *$ \\
Running the uniform, book, and stationary & $90 \%$ & $70 \%$ & $17.00^{* * *}$ \\
shops & & & \\
School socials & $86 \%$ & $40 \%$ & $55.72 * * *$ \\
School events (e.g. concerts, sports days) & $95 \%$ & $58 \%$ & $68.94 * * *$ \\
Parents and children together activities & $95 \%$ & $57 \%$ & $63.02^{* * *}$ \\
Assemblies & $74 \%$ & $26 \%$ & $58.74 * * *$ \\
Excursions & $60 \%$ & $14 \%$ & $48.76^{* * *}$ \\
\hline
\end{tabular}

$* * p<.01 . * * * p \leq .001$.

\subsection{Principal leadership surrounding parent engagement}

The majority of Principals appear to have a mostly collaborative leadership style and to value parent involvement in their school, as rated by themselves and $\mathrm{P} \& \mathrm{C}$ Presidents. For example: 90\% of Principals state that they try to include staff and/or parents in the decision making processes about school matters and 73\% of P\&C Presidents agreed; 93\% of Principals feel that they play an integral role in promoting parent engagement in their school and $77 \%$ of P\&C Presidents agreed. An inconsistency emerged in that, as mentioned previously, only $35 \%$ of Principals expected parent involvement in school governance, yet $75 \%$ of Principals agreed that school governance is a shared responsibility with the school community (and 66\% of P\&C Presidents believe that their Principal takes this view). Almost 20\% of Principals 
considered that parents were not well-equipped to be active participants in school governance and Principals were no more or less likely to think this in disadvantaged schools. This suggests that negative views about parental involvement in school governance are entrenched in a sizeable minority of Principals irrespective of school context. In fact, responses did not differ systematically on any of the leadership items according to school ICSEA, location or type, suggesting that these factors do not determine a Principal's leadership style as it relates to parent engagement.

\subsection{Relationships between parents and the school}

Almost all Principals agreed they had strong relationships with parents - a sentiment echoed by approximately $75 \%$ of $\mathrm{P} \& \mathrm{C}$ Presidents. For both groups, the vast majority agreed that parents were given opportunities to voice issues and concerns. While $100 \%$ of Principals stated that they treat parents with respect, only $88 \%$ of P\&C Presidents indicated that their school's Principal treat parents with respect. Similarly, while 97\% of Principals agreed that parents in their school trust them, only $89 \%$ of P\&C Presidents agreed with this statement concerning their school's Principal. Furthermore, Principals and P\&C Presidents differed in their agreement that parents should obey school rules even when it goes against what they think is right (69\% of P\&C Presidents versus $85 \%$ of Principals) and agreement that parents should accept decisions made by the school even if they disagree (43\% of P\&C Presidents versus $62 \%$ of Principals). Responses to these items did not differ significantly according to school type, zone or ICSEA.

The vast majority of Principals reported positive attitudes towards the school P\&C Association. Only $8 \%$ of Principals agreed that the P\&C took up too much of their time, $9 \%$ felt that the P\&C was ineffective, and $4 \%$ felt that the school would be better off without a P\&C. Responses to these items did not differ across school zone, type or ICSEA. This is consistent with the Principal leadership findings reported above. While a sizeable minority of Principals did not support parent involvement in school governance, a smaller minority did not appear to hold positive attitudes regarding parent involvement even in the form of the $\mathrm{P} \& \mathrm{C}$ Association. These views were held regardless of a school's location or type. The consequences of Principals holding such views for a school's climate and levels of parent engagement represent important areas for future research. 


\subsection{Communicating with parents}

Principals were asked how often certain means of communication were used to share school or student related information with parents. The daily communication about student related information occurred mostly via phone (64\%) and email (32\%). School related information was mostly shared with parents fortnightly via electronic (51\%) and printed (48\%) school newsletter. Assemblies were mostly used weekly (78\%) and parent information meetings were used a few time s a year (74\%) to share school related information with parents. Most of the schools combined the use of electronic and printed newsletter (69\%); only $15 \%$ of schools exclusively used printed and only $15 \%$ exclusively used electronic school newsletters. In terms of school zone and means of communication, it appeared that schools in metropolitan areas were the most likely to use the electronic school newsletter exclusively $\left(\chi^{2}(6, N=382)=38.78\right.$, $p<.001)$. Similar results were found regarding the daily use of phone calls $\left(\chi^{2}(12, N=383)=\right.$, $p<.001)$ and emails $\left(\chi^{2}(12, N=350)=40.08, p<.001\right)$ to share student related information with parents.

Communication between schools and the parent body was found to occur more frequently in primary compared with secondary schools. For example, primary schools were more likely than secondary schools to communicate via electronic newsletter weekly, and secondary schools were more likely to do so monthly $\left(\chi^{2}(9, N=323)=62.31, p<.001\right)$. Similar differences between primary and secondary schools were found for frequency of communication via printed newsletter $\left(\chi^{2}(12, N=325)=47.09, p<.001\right)$ and assemblies $\left(\chi^{2}\right.$ $(12, N=369)=75.24, p<.001)$. Increasing the frequency of communication between secondary schools and their parent body could be one possible strategy employed to build and strengthen parent-school partnerships in these schools, although future research would need to examine the strategy's effectiveness.

Principals and P\&C Presidents were asked to identify the best ways of finding out what parents want and need, and both rated P\&C meetings, word of mouth and meetings with individual parents as the most important. This suggests that parent organisations such as $\mathrm{P} \& \mathrm{C}$ Associations are an important channel for communication between Principals and parents; their role in strengthening parent-school partnerships is an area worthy of further investigation. 


\section{Discussion}

\subsection{Principal leadership}

Principal's expectations and attitudes can have a significant impact on school climate, and the extent to which parents engage with their child's school and participate in their broader academic development (Barr \& Saltmarsh, 2014; Mleczko \& Kington, 2013). Based on their own self-reports, the Principals in this study appeared to have very positive attitudes towards parent engagement. They widely endorsed all of the proposed benefits of parent engagement in child learning, held high expectations for parent involvement in student learning, school events and fundraising, reported very positive relationships with the parents in their school and perceived their school's P\&C Association in a positive light. However, these reposnses are likely to be somewhat skewed by the phenomenon of social desirability bias (see Tourangeau, Rips, \& Rasinski, 2000). Indeed, some discrepancies were found between how P\&C Presidents perceived their Principal and how Principals perceived themselves, with around one-fifth of P\&C Presidents reporting that their Principal did not collaborate and engage with the parents in their school. It is possible that these results reflect the fact that the samples of Principals and P\&C Presidents did not completely overlap and as such represent somewhat different schools. Forthcoming manuscripts will explore contradictions between Principal and P\&C President survey responses using the subsample of 169 schools from which both Principal and P\&C President responses were received.

While Principals' attitudes towards parent engagement were found to be positive overall, around one-fifth of Principals did not support parent involvement in school governance, and a smaller minority held negative views about the school's P\&C Association. These attitudes appear to arise from within the Principals themselves, as their occurrence did not differ systematically according to contextual factors such as school location or disadvantage. The potential impacts of Principals holding such views is concerning. Principals who think this way are unlikely to support parent involvement in school governance or curriculum even when structures are present or available. This means that the cycle of traditional parent engagement in schools is continued and opportunities for increased engagement are missed. In this instance the outlook for parents in disadvantaged schools is the direst. 


\subsection{School climate}

The notion that school climate significantly impacts on levels of parent engagement (HooverDempsey et al., 2005) is supported by the finding that the engagement strategy most likely to be rated as effective by both Principals and $\mathrm{P} \& \mathrm{C}$ Presidents was 'creating a respectful and welcoming environment'. Aspects of school climate, such as a lack of communication between parents and teachers and a lack of trust in the responsiveness of the school to parent concerns, were identified as reducing parent involvement in approximately $25 \%$ of schools. Forthcoming work will focus on modelling relationships among Principal leadership styles, perceptions of school climate, parent involvement in the school and child learning outcomes.

\subsection{Disadvantaged schools}

It is well documented that disadvantaged parents, which in Australia would include Indigenous parents and those from lower socio-economic statuses, tend to have lower levels of engagement in their child's school and learning, and face additional barriers to engagement when compared to more advantaged parents (Day, 2013; Hanafin \& Lynch, 2002; Kim, 2009; Parental Engagement Project Taskforce, 2011). Hence, the results of this study are consistent with previous findings. Although Principals from lower ICSEA schools were just as likely as those from higher ICSEA schools to report using a range of engagement strategies, they were significantly less likely to find many methods effective in involving parents in their school. Furthermore, a less positive culture of parent volunteerism was reported by $\mathrm{P} \& \mathrm{C}$ Presidents from lower ICSEA schools. This suggests that those schools in which the children stand to gain the most from increasing levels of parent engagement, are the same schools finding their efforts to engage parents the least effective. It highlights the need to identify what does work in disadvantaged schools and to ensure that interventions are tailored to the specific needs of these schools, as applying uniform strategies across all schools may only compound the advantage of those already doing well.

Principals in this study emphasised different barriers to parent involvement according to the school's ICSEA value. In higher ICSEA schools, time-pressure factors such as work and family responsibilities were more likely to be identified, whereas in lower ICSEA schools parent factors such as a lack of interest and a lack of confidence were more likely to be identified, along with transportation problems. This information can be used to guide interventions in disadvantaged schools. 


\subsection{Secondary schools}

This study identified a range of differences between primary and secondary schools, which is unsurprising given that previous research has consistently demonstrated decreasing levels of parent involvement in schools as children enter adolescence. While it has been argued that this may be a developmentally appropriate phenomenon, parent involvement in schools has still been found to have positive, if indirect, associations with adolescent learning outcomes. It may therefore be of some concern that secondary principals have significantly lower expectations for parent involvement in many aspects of school life, communicate less frequently with the parent body, and are less likely to identify parent self-development as a benefit of parent engagement. A range of engagement strategies were significantly less likely to be effective in secondary schools, and it is possible that this may, in part, be reflective of declining parent confidence and the perception of a more unwelcoming school environment as children enter secondary school, as identified by $\mathrm{P} \& \mathrm{C}$ Presidents. These findings provide useful starting points for those secondary schools seeking to strengthen partnerships with parents.

\subsection{Limitations}

A limitation of this research is that it included only the perspectives of the school Principal and P\&C President. Future analyses will address this by linking the PES survey data with data from Queensland Department of Education and Training School Opinion Surveys of parents, teachers and students.

\section{Conclusions}

This paper has outlined the methodology and described the baseline findings of the PES surveys, which are part of a larger project investigating how school climate, Principal leadership and parent organisations contribute to levels of parent engagement in Australian schools. This paper has described how Queensland State schools differ from one another on factors including Principal leadership, effective engagement strategies, barriers to engaging parents, and parent volunteerism. Future work will incorporate the perspectives of parents, teachers and students; profile schools according to Principal leadership style; and model relationships among Principal leadership, school climate, parent engagement and child learning outcomes. This will inform the development of interventions to increase levels of parent engagement in schools, with the ultimate aim of improving the learning outcomes of children not only in Australia but also overseas. 


\section{References}

Australian Bureau of Statistics. (2015). Regional population growth, Australia, 2013-2014 (Report No. 3218.0). Retrieved from http://www.abs.gov.au/AUSSTATS/abs@.nsf/Latestproducts/3218.0Main\%20Features30201 3-14?opendocument $\&$ tabname $=$ Summary $\&$ prodno $=3218.0 \&$ issue $=2013-14 \&$ num $=\& v i e w=$

Australian Curriculum, Assessment and Reporting Authority. (2015). National assessment program literacy and numeracy: National Report for 2015. Retrieved from http://www.nap.edu.au/verve/_resources/2015_NAPLAN_national_report.pdf

Barnes, G. (2010). Report on the generation of the 2010 Index of Community Socio-Educational Advantage (ICSEA). Retrieved from http://www.acara.edu.au/verve/_resources/ICSEA_Generation_Report.pdf

Barr, J., \& Saltmarsh, S. (2014). It all comes down to the leadership: The role of the school principal in fostering parent-school engagement. Educational Management Administration \& Leadership, 42(4), 491-505. doi: 10.1177/1741143213502189

Castro, M., Expósito-Casas, E., López-Martín, E., Lizasoain, L., Navarro-Asencio, E., \& Gaviria, J. L. (2015). Parental involvement on student academic achievement: A meta-analysis. Educational Research Review, 14, 33-46. doi: http://dx.doi.org/10.1016/j.edurev.2015.01.002

Chazan-Cohen, R., Raikes, H., Brooks-Gunn, J., Ayoub, C., Pan, B.A., Kisker, E.,...Fuligni, S.A. (2009). Low-income children's school readiness: Parent contributions over the first five years. Early Education and Devlopment, 20(6), 958-977. doi: 10.1080/10409280903362402

Cheung, C., Lam, C., \& Ngai, S. (2008). Help from the parent-teacher association to parenting efficacy: Beyond social status and informal social capital. Journal of Socio-economics, 37(3), 1134-1152. doi: 10.1016/j.socec.2006.12.068

Council of Australian Governments. (2013). National Educaiton Reform Agreement. Retrieved from http://www.federalfinancialrelations.gov.au/content/npa/education/nationalagreement_201412.pdf

Day, S. (2013). "Terms of engagement" not "hard to reach parents". Educaitonal Psychology in Practice, 29(1), 36-53. doi: 10.1080/02667363.2012.748649 
Dauber, S. L., \& Epstein, J. L. (1989). Parents' attitudes and practices of involvement in inner-city elementary and middle schools (Report No. 33). Baltimore, MD: Center for Research on Elementary and Middle Schools.

Department of Education and Training, Australian Government. (2015a). Schooling. Retrieved from https://www.education.gov.au/schooling

Department of Education and Training, Australian Government. (2015b). Students first. Retrieved from https://www.studentsfirst.gov.au/

Department of Education and Training, Australian Government. (2015c). Making my school better. Retrieved from https://docs.education.gov.au/system/files/doc/other/makingmyschoolbetter.pdf

Doecke, B., Parr, G., North, S., Gale, T., Long, M., Mitchell, J. et al. (2008). National mapping of teacher professional learning project: Final report. Canberra: Department of Education, Employment and Workplace Relations.

Drysdale, L., Goode, H., \& Gurr, D. (2009). An Australian model of successful school leadership: Moving from success to sustainability. Journal of Educational Administration, 47(6), 697708. doi: http://dx.doi.org/10.1108/09578230910993087

Eccles, J.S., \& Harold, R.D. (1996). Family involvement in children's and adolescent's schooling. In A. Booth \& F.J. Dunn (Eds.), Family-school links: How do they affect educational outcomes? (pp. 3-33). Hillsdale, NJ: Erlbaum.

Education (General Provisions) Act 2006 (Qld). Retrieved from https://www.legislation.qld.gov.au/LEGISLTN/CURRENT/E/EducGenPrA06.pdf

Ekundayo, H. T., \& Alonge, H. O. (2012). Strengthening the Roles of Parent Teacher Association in Secondary Schools for Better Community Participation in Educational Development in Nigeria. Journal of Educational and Developmental Psychology, 2(2), 16. doi: 10.5539/jedp.v2n2p16

Emerson, L., Fear, J., Fox, S., \& Sanders, E. (2012). Parental engagement in learning and schooling: Lessons from research. Retrieved from http://www.aracy.org.au/publicationsresources/command/download_file/id/7/filename/Parental_engagement_in_learning_and_sch ooling_Lessons_from_research_BUREAU_ARACY_August_2012.pdf 
Epstein, J. L. (1990). School and family connections: Theory, research, and implications for integrating sociologies of education and family. Marriage and Family Review, 15(1-2), 99126.

Epstein, J. L. (2011). School, family, and community partnerships: Preparing educators and improving schools (2nd ed.). Boulder, CO: Westview Press.

Fantuzzo, J., McWayne, C., Perry, M.A., \& Childs, S. (2004). Multiple dimensions of family involvement and their relations to behavioural and learning competencies for urban, lowincome children. School Psychology Review, 33(4), 467-480. Retrieved from http://search.proquest.com/docview/219645403?accountid=14723

Fox, S. \& Olsen, A. (2014). Education capital: Our evidence base. Defining parental engagement. Canberra: Australian Research Alliance for Children and Youth.

Garcia, D. C. (2004). Exploring connections between the construct of teacher efficacy and family involvement practices: Implications for urban teacher preparation. Urban Education, 39(3), 290-315. doi: 10.1177/0042085904263205

Gavidia-Payne, S., Denny, B., Davis, K., Francis, A., \& Jackson, M. (2014). Children's self-concept: Parental school engagement and student-teacher relationships in rural and urban Australia. Social Psychology of Education, 18(1), 121-136. doi: 10.1007/s11218-014-9277-3

Gianzero, G. (1999). Promoting parental involvement: Improving student outcomes. San Diego Dialogue. Retrieved from https://edadm821.files.wordpress.com/2011/02/parentalinvolvement-doc.pdf

Giles, C. (2006). Transformational Leadership in Challenging Urban Elementary Schools: A Role for Parent Involvement? Leadership and Policy in Schools, 5(3), 257-282. doi: $10.1080 / 15700760600805865$

Goldkind, L., \& Farmer, G. L. (2013). The Enduring Influence of School Size and School Climate on Parents' Engagement in the School Community. School Community Journal, 23(1), 223-244. Retrieved from http://search.proquest.com/docview/1406196554?accountid=14723

Goodall, J., \& Montgomery, C. (2014). Parental involvement to parental engagement: a continuum. Educational Review, 66(4), 399-410. doi: 10.1080/00131911.2013.781576 
Gordon, M.F., \& Louis, K.S. (2009). Linking Parent and Community Involvement with Student Achievement: Comparing Principal and Teacher Perceptions of Stakeholder Influence. American Journal of Education, 116(1), 1-31. doi: 10.1086/605098

Gow, C. (2008). Parents and Citizen's Associations in the Riverina 1921 - 1991: Their role and function in schools and communities. CSURA Research Scholarships. Charles Sturt University. Retrieved from http://www.csu.edu.au/research/archives/summer-scholarships

Griffith, J. (1998). The Relation of School Structure and Social Environment to Parent Involvement in Elementary Schools. The Elementary School Journal, 99(1), 53-80. doi: 10.1086/461916

Hanafin, J., \& Lynch, A. (2002). Peripheral voices: Parental involvement, social class, and educational disadvantage. British Journal of Sociology of Education, 23(1), 35-49. doi: $10.1080 / 01425690120102845$

Harris, A., \& Goodall, J. (2007). Engaging parents in raising achievement: Do parents know they matter?(Report No. DCSF-RW004). Retrieved from http://library.bsl.org.au/jspui/bitstream/1/3469/1/Engaging\%20parents\%20and\%20raising\%2 0achievement_Alma\%20Harris_2007\%20.pdf

Hayes, D. (2011). Predicting parental home and school involvement in high school African American adolescents. The High School Journal, 94(4), 154-166.

Henry, K. L., \& Huizinga, D. H. (2007a). School-related risk and protective factors associated with truancy among urban youth placed at risk. Journal of Primary Prevention, 28(6), 505-519. doi: 10.1007/s10935-007-0115-7

Henry, K. L., \& Huizinga, D. H. (2007b). Truancy's effect on the onset of drug use among urban adolescents placed at risk. Journal of Adolescent Health, 40, 9-17. doi:10.1016/j.jadohealth.2006.11.138

Hill, N. E., \& Taylor, L. C. (2004). Parental school involvement and children's academic achievement: Pragmatics and issues. Current Directions in Psychological Science, 13(4), 161-164. doi:10.1111/j.0963-7214.2004.00298.x

Hill, N. E., \& Tyson, D.F. (2009). Parental Involvement in Middle School: A Meta-Analytic Assessment of the Strategies That Promote Achievement. Developmental Psychology, 45(3), 740-763. doi: 10.1037/a0015362 
Hoover-Dempsey, K., Walker, J., Sandler, H., Whetsel, D., Green, C., Wilkins, A., \& Closson, K. (2005). Why do parents become involved? Research findings and implications. The Elementary School Journal, 106(2), 105-130. doi:10.1086/499194

I-wah, P. (1997). Functions of the Parent-Teacher Association (PTA): A Hong Kong Perspective. Chinese University Education Journal, 25(1), 81. Retrieved from http://eric.ed.gov/?id=ED399607

Jeynes, W. H. (2005). A meta-analysis of the relation of parental involvement to urban elementary school student academic achievement. Urban Education, 40(3), 237-269. doi: $10.1177 / 0042085905274540$

Kaplan Toren, N., \& Seginer, R. (2015). Classroom climate, parental educational involvement, and student school functioning in early adolescence: a longitudinal study. Social Pyschology of Education, 18(4), 811. doi: 10.1007/s11218-015-9316-8

Kelso, R. (2013). Quick guide for P\&C executive officers: parents performing a vital role in the education of their children! Retrieved from http://education.qld.gov.au/parents/pdf/quickguide-pc-executiveofficers.pdf

Khong, L. Y.-L., \& Ng, P. T. (2005). School-Parent Partnerships in Singapore. Educational Research for Policy and Practice, 4(1), 1-11. doi: 10.1007/s10671-005-5617-6

Kim, Y. (2009). Minority parental involvement and school barriers: Moving the focus away from deficiencies of parents. Educational Research Review, 4(2), 80-102. doi: http://dx.doi.org/10.1016/j.edurev.2009.02.003

McNeal, R.B. (2001). Differential effects of parental involvement on cognitive and behavioural outcomes by socioeconomic status. Journal of Socio-Economics, 30(2), 171-179. doi: $10.1016 / \mathrm{S} 1053-5357(00) 00100-1$

Ministerial Council for Education, Employment, Training and Youth Affairs [MCEETYA]. (2008). Melbourne Declaration on Educational Goals for Young Australians. Retrieved from http://www.curriculum.edu.au/verve/_resources/National_Declaration_on_the_Educational_ Goals_for_Young_Australians.pdf

Mistry, R.S., Benner, A.D., Biesanz, J.C., \& Clark, S.L. (2010). Family and social risk, and parental investments during the early childhood years as predictors of low-income children's school 
readiness outcomes. Early Childhood research Quarterly, 25, 432-449.

doi:10.1016/j.ecresq.2010.01.002

Mleczko, A., \& Kington, A. (2013). The Impact of School Leadership on Parental Engagement: A Study of Inclusion and Cohesion. International Research in Education 1(1), 129-148. doi: http://dx.doi.org/10.5296/ire.v1i1.3844.

National School Climate Council. (2007). The school climate challenge: Narrowing the gap between school climate research and school climate policy, practice guidelines and teacher education policy. Retrieved from http://community-matters.org/downloads/school-climate-challengepolicy-paper.pdf

National School Climate Council. (2016). FAQ about school climate. Retrieved from http://www.schoolclimate.org/climate/faq.php

Ozmen, F., \& Canpolat, C. (2010). The efficiency of School-Parent Associations (SPA) at schools. Procedia - Social and Behavioral Sciences, 9, 1947-1954. doi: 10.1016/j.sbspro.2010.12.428

P\&Cs Qld. (2016). About P\&Cs Qld. Retrieved from http://www.pandcsqld.com.au/about-us/aboutpcs-qld/

Pakseresht, S., \& Ahari, A. E. (2014). Investigating the effectiveness of parent-teacher association activities in elementary schools of region 8 of Tehran. Arabian Journal of Business and Management Review, 3(11a), 194-202. Retrieved from http://search.proquest.com/docview/1547710400?accountid=14723

Parental Engagement Project Taskforce. (2011). Parental engagement in schooling in low socioeconomic status communities. Retrieved from https://docs.education.gov.au/system/files/doc/other/parental_engagement_0.pdf

Payne, M., Hinds, J., \& Gay, L. (1986). Parent-teacher relationships: Perspectives from a developing country. Educational Research, 28(2), 117-125. doi: 10.1080/0013188860280206

Perkins, K., \& Knight, P. (2014). Queensland college of teachers research digest (No. 10). Retrieved from http://www.qct.edu.au/Publications/Periodical/QCTResearchDigest2014-10.pdf

Powell, D. R., Son, S., File, N., \& San Juan, R.R. (2010). Parent-school relationships and children's academic and social outcomes in public school pre-kindergarten. Journal of School Psychology, 48(4), 269-292. doi:10.1016/j.jsp.2010.03.002 
Queensland Government. (2012). Census 2011: Queensland's population compared. Retrieved from http://www.qgso.qld.gov.au/products/reports/qld-pop-compared-c11/qld-pop-comparedc11.pdf

Sénéchal, M., \& Young, L. (2008). The effect of family literacy interventions on children's acquisition of reading from kindergarten to grade 3: A meta-analytic review. Review of Educational Research, 78(4), 880-907. doi: 10.3102/0034654308320319

Shakur, C. R. (2012). An analysis of barriers to and strategies for improving parent engagement (Master's thesis, Loyola University, Chicago, U.S.A). Retrieved from http://ecommons.luc.edu/cgi/viewcontent.cgi?article=1727\&context=luc_theses

Sheldon, S. B., \& Epstein, J. L. (2005). Involvement counts: Family and community partnerships and mathematics achievement. Journal of Educational Research, 98(4), 196-206. Retrieved from http://www.jstor.org/stable/27548080

StataCorp. (2015). Stata statistical software: Release 14. College Station, TX: StataCorp LP.

Stranger, M. (2002). Student absence from school and juvenile crime: Project report. Canberra: Attorney-General's Department.

Thomson, S. (2013). Declining PISA outcomes: Time to stop the slide. Australian Council for Educational Research: Research Developments. Retrieved from https://rd.acer.edu.au/article/declining-pisa-outcomes-time-to-stop-the-slide

Thomson, S., De Bortoli, L., \& Buckley, S. (2012). PISA 2012: How Australia measures up. Retrieved from https://www.acer.edu.au/documents/PISA-2012-Report.pdf

Toldson, I.A., \& Lemmons, B.P. (2013). Social demographics, the school environment, and parenting practices associated with parents' participation in schools and academic success among Black, Hispanic, and White students. Journal of Human Behaviour in the Social Environment, 23(2), 237-255. doi: 10.1080/10911359.2013.747407

Tourangeau, R., Rips, L. J., \& Rasinski, K. A. (2000). The psychology of survey response. Cambridge, New York: Cambridge University Press.

Turney, K., \& Kao, G. (2009). Barriers to school involvement: Are immigrant parents disadvantaged? The Journal of Educational Research, 102(4), 257-271. doi: 10.3200/JOER.102.4.257-271 
Van Voorhis, F.L., Maier, M.F., Epstein, J.L., \& Lloyd, C.M. (2013). The impact of family involvement on the education of children ages 3 to 8: A focus on literacy and math achievement outcomes and social-emotional skills. Retrieved from http://www.mdrc.org/sites/default/files/The_Impact_of_Family_Involvement_FR.pdf

Wallace, M. (2013). High school teachers and African American parents: A (not so) collaborative effort to increase student success. The High School Journal, 96(3), 195-208. doi: 10.1353/hsj.2013.0008

Wang, M., \& Sheikh-Khalil, S. (2014). Does parental involvement matter for student achievement and mental health in high school? Child Development, 85(2), 610-625.

Watkins, T.J. (1997). Teacher communications, child achievement, and parent traits in parent involvement models. The Journal of Educational Research, 91(1), 3-14.

Whitaker, M., \& Hoover-Dempsey, K. (2013). School influences on parents' role beliefs. The Elementary School Journal, 114(1), 73-99. doi: 10.1086/671061

Wilson, R., Dalton, B., \& Baumann, C. (2015). Six ways Australia's education system is failing our kids. The Conversation. Retrieved from https://theconversation.com/six-ways-australiaseducation-system-is-failing-our-kids-32958

Zill, N., \& Nord, C. W. (1994). Running in place: How American families are faring in a changing economy and an individualistic society. Washington, DC: Child Trends Inc. 